\title{
Customer Service Approach on Determinants of Marriage Satisfaction
}

\section{Siti Norashikin Bashirun', Nur Idayu Badrolhisam², Nurhafizah Mohd Zolkapli ${ }^{3}$, Farah Shazlin Johari ${ }^{4}$, and Nor Maslia Rasli Samudin ${ }^{5}$}

\author{
1Universiti Teknologi MARA, Melaka and Malaysia, \\ $\square$ (e-mail) sitinorashikin3639@bdrmelaka.uitm.edu.my \\ ${ }^{2}$ Universiti Teknologi MARA, Melaka and Malaysia, \\ $\square$ (e-mail) nur_idayu24@uitm.edu.my. \\ ${ }^{3}$ Universiti Teknologi MARA, Melaka and Malaysia, \\ $\square$ (e-mail) nurhafizahzolkapli@bdrmelaka.uitm.edu.my \\ ${ }^{4}$ Universiti Teknologi MARA, Melaka and Malaysia, \\ $\square$ (e-mail) farahshazlin@bdrmelaka.uitm.edu.my \\ ${ }^{5}$ Universiti Teknologi MARA, Melaka and Malaysia, \\ $\triangle$ (e-mail) maslia_samudin@bdrmelaka.uitm.edu.my
}

\begin{abstract}
Satisfaction is a universal concept that can be seen as important in marriage institution. In organization customer satisfaction, it is one of the main goals to be achieved; this could be similar in the marriage relationship whereby couples are searching for their marriage satisfaction. To achieve it, spouses need to have their own strategy and to work on it. Moreover, there are a few factors that determine satisfaction in marriage life. Previous research on the service dimension in marriage life has found the new perspective and similarity. Nowadays we can see the increase in the divorce rates and all parties should take it seriously so that it will not become a social problem in society. The main purpose of this study is to identify determinants of marriage satisfaction by implementing the customer service approach and focusing on customer satisfaction dimension towards marriage satisfaction. This research was conducted using a set of questionnaire to 190 married couples, whereby five Likert-scale questionnaires used as an instrument to gather the data. Majority respondent agreed that "reward" is the most factor dimension that influence on marriage satisfaction. In general, results indicate five dimensions that were correlated with marriage satisfaction, namely, reward, communication, behavior and responsiveness, activities and productivity. Married counselors and couples should be aware regarding this new perspective on customer service dimension so that improvement in marriage relationship can be achieved.
\end{abstract}

Keywords: customer satisfaction, customer service, marriage relationship, and marriage satisfaction

\section{Introduction}

Satisfaction is one of the common concepts that intangibly to be measured. In service, satisfaction can be one of the achievements for the organization to be achieved by their customer and its becoming very important and being part of organization activities. This should be maintaining in order to make customer happy and being a part of organization's goal. In marriage life, satisfaction could also be a goal for spouses. There are many factors contribute to achieve marriage satisfaction, failure to meet it will cause dissatisfied and may end up with unhappiness. Nowadays, the increase rate on divorce issue and many studies has been done to identify the factors contribute to the dissolution of marriage, impact to the society and other study on marriage psychology.

Few studies have investigated the other perspective that have relevancy with marriage life such as the customer service perspective that could be implement in our daily life. The goal of customer service is satisfaction, thus, this study represented the customer service approach in marriage life in order to see its relevancy and whether it could be implemented and retain by married couple due to 
achieve their marriage satisfaction. Customer satisfaction based approach is a universal theory and have similarity with the marital adjustment in marriage that is suitable for organization and marriage life (Rika Fatimah et al 2007, Rika Fatimah 2012). Moreover, quality dimension in organization has been seen as satisfaction, customer loyalty, service quality, productivity, effectiveness and efficiency in order to improve organizational performance.

Customer commitment, customer satisfaction and service quality have been found and these characteristics has match with dimensions of marriage that are marital relationship, marital adjustment and marital intimacy (Rika Fatimah, 2012). Based on this study, it shows that customer service is a broad theory that may not only for a service organization but also could be implementing in our daily life. The customer satisfaction may affect customer's perception towards loyalty and its relationship (Yaya et al., 2011). Moreover, Fatimah et al. (2009) have discovered a new dimension on the quality of perspective that being used in determining the priority in marriage life that may commence relationship loyalty and marriage satisfaction. The increase of loyal customer's retention is the key factor for a long-term success of the companies (Akher at al., 2011).

In organizations, customers can be identified as external and internal customers like a patient comes to the clinic and a student studies in university. Whereas, in marriage institution, husband and wife is the customer whereby both are giving service to each other. Fatimah et al. (2012), also found the similarity of "family relationship" and "service strategy" which then translated in term of longevity of relationship in marriage life and in organization itself. Factors that contribute to the longevity of happy marriage were numerous and tend to be unique for each married couple (Bachand \& Caron, 2001). Hence, couples in marriage relationship are working to satisfy each other that may affect their loyalty in relationship. This new perspective will bring a new concept and perhaps can be contributed to the marriage institution. The dimension is matched and thus, this research focused on the factors use in organization to sustain their customer satisfaction that to be implemented in the marriage institution. Then, this study emphasized the factors that may influence spouse in satisfying to each other and, in the end, it could be led to the marriage satisfaction.

Many factors can be determined on the increasing of divorce cases such as the couple less on religious education, immature attitude, not positive and failure to carry out the trust, duties and relationship of each other (Shafiza, 2011). Study should be carried out in order to reduce the number and to educate spouse regarding the vital issue of marriage satisfaction. Abdul Razak et al., (2011) described that there are a lot of effort that has been put due to solving marital problems, however the results are not encouraging and this need to be investigated in order to understand how to enrich marriages among Malays in Malaysia.

Hence, the objectives of this study are to verify marital satisfaction by using the customer service approach. This is because the dissatisfaction in marriage life may contribute to the unhappy relationship and at the end may end up with the dissolution of marriage. Marriages end and divorce becoming a phenomenon at many places. The numbers of divorce cases in Malaysia should be look seriously by the community so that it would not destroy the marriage institution. Statistic from Sharia Judiciary Department of Malaysia in October 2016 showed that about 48077 divorce cases was reported among Muslims, moreover Statistic from National Registration Department of Malaysia in July 2017 showed that total numbers of divorce cases among non-Muslim was 91120 cases from 2007 2017.

This also could give another impact in society that will create another social issue such as distressed children and stress at the workplace. Therefore, this study is undertaken to determine marriage satisfaction by implementing customer service approach in focusing on customer satisfaction dimension. Moreover, this study determined the most couple satisfaction factor that has influenced marriage institution. 


\section{Marriage relationship}

Marriage is a contract between men and women and the union that allows them to share together through thick and thin, perform responsibilities as husband, wife and parents and work together to face their life (Haikal, 2007). The new perspective is to improve the quality of marriage by making use of the experience in organization and meet with customer needs (Fatimah et al., 2009; Fatimah 2012). There is a positive connection between marriage and healthiness of couples and in contrast, unhappy and unhealthy marriages tend to have negative effects to the physical and mental health. Having quality in marriage life will lead to the satisfaction and recent study shows that it is also affects health (Staton, 2010). Additionally, the married couple normally has better wealth on their physical and mental as compared to those who are not getting married, divorce and separated (Saxbe \& Rapetti, 2008). Unhappy marriage and low quality of marriage will make people suffer from overall happiness, lack of life satisfaction, lower self-esteem and low health condition. This normally happen to the short-term marriage as compared to the long term happy marriage. All these negatives impact of unhappy marriage is still being a little concern by many people (Hawkin \& Booth, 2005). Hence, it is assumed that customer service dimension could be applied in daily life especially in marriage institution to improve satisfaction.

Next, Brown (2004) has discussed that if the couple is always feel satisfy to each other, then any conflict that might occur during the relationship is able to be minimized or even avoided. However, in reality, it is hard to satisfy each other when delivering service to the spouse. Therefore, it is better to prevent the marriage problem rather than solving the problem. Septy and Zulkaida (2013) concluded that marriage satisfaction being influenced by dominant factors to the working wife is an interpersonal relationship with spouse, suitability and expectation, communication with spouse, in common interest, conflict ability, and finance. Communication is critical to ensure couple can survive, stabilize and grow. Failed to possess communication skills can lead to failed marriage (Farzaneh et al., 2016).

There are many challenges face in marriage including the economic factor. Dakin and Wampler (2008) concluded that finance management may affect in marriage relationship and this is one of the important factors in order to achieve satisfaction. Couples with low- and middle-income level tend to show their dissatisfaction towards marriage relationship and end up with dissolutions. Economic status can explain marital satisfaction and increases marital satisfaction. It is showed that families who have a stability of economic status are more social satisfaction (Hossein \& Sadghi, 2016); thus, will lessen the argument in family. Staton (2010) explains that marriage is an investment to gain satisfaction in life and financial stability is consider important because it is also will give an impact to the health of spouse and their children, thus decision on financial matter in marriage relationship need to be taken care

\section{Customer satisfaction}

There are three general components can be identified in customer satisfaction: 1) consumer satisfaction is a response (emotional); 2) the response is pertaining to a particular focus (expectations); 3 ) the response is pertaining to a particular time (experience) (Joan \& Joseph, 2000). If we study these three elements, it is a part of marriage institution whereby emotional, expectations and experience feel by customer could also be the feeling of the spouse. Rika Fatimah (2012) supported that customer satisfaction is one of the common thought in organization that can be exploiting in order to measure marriage satisfaction among spouse.

Customer satisfaction can be dependent and it is gone through the experience of customers with the service delivery process and they tend to be more satisfied when the perception on services provided exceeds their expectations (Jalal et al., 2011Factors of employee responsiveness, appearance of tangibles, services innovation, and competence has significant to the customer satisfaction (Singh and Kaur, 2011). 
Furthermore, Hansemark and Albinson (2004) defined that satisfaction is an overall customer feelings towards a service provider or organization, or it can also be an emotional reaction to the differences between what they expect and what they receive in order the fulfill their need, goal or desire from that particular provider or organization. To achieve it, organization must focus on their customers and retain them well by providing high quality services that at the end will satisfy them. Moreover, delivering better service to the end customer is consider a key driver that portrays goodwill of organization and will contribute to satisfaction. It also involves psychological process that at the end shows a win-win situation in providing good service (Jalal, 2011).

\section{Factors determining marital satisfaction by using customer service approach}

Trustworthiness of firm plays an important role in building loyalty towards products or services provided. Business gives the importance of customer's relationship with customer's satisfaction, where trustworthiness and better image in crucial in the market place. Customer who is satisfied with the offerings and services would be the most loyal customer of the company. Besides that, customer satisfaction is also very important in ensuring customer loyalty and retention. Organization should always strive to ensure that their customers are very satisfied. Friendly and helpful employees, quick service, courteous, knowledgeable are the factors that affect customer satisfaction (Hokansol 1995 in Singh, 2006). Thus, it is concluded that satisfied customer will lead to the loyalty (Waheed et al., 2011).

Reward system can help to satisfy the customer needs. Although sometimes customers didn't realize receiving discount and other hidden benefit are the form of reward system, organization can always pay attention on this matter for them to retain the customers to enhance customers' loyalty (Zeithaml, 2009). Other than that, the element of communication plays as an important factor to satisfy the customer need (Kaur Kiran, 2010). Vukmir (2006) stated that a patient clearly values the good communication occur in the hospital that will resulted on the establishment of trust and loyalty toward the hospital services and employees. Likewise, Fatimah (2012) mentioned that in order to improve marriage relationship one should be provided with higher level of education so that they are being able to communicate well with their partner, and she also suggested the spouse to attend communication course to improve their level of communication.

On the other hand, a customer in banking sector feels content with the international banks because the offers better service especially in terms of quality. Ismah et al. (2009) suggest that the Islamic bank to sustain their market positioning by certifying that there is service quality entail on customer satisfaction and ultimately customer loyalty. In order to form positive perception towards quality, Jalal (2011) and Zeithaml (2009) suggest responsiveness as by providing prompt assistance to the customers whereby employees are ready to respond to the customer's need effectively and perhaps quick service. It is a matter of dealing with customer requests, questions and complaint in a good manner.

Next, Bachand and Caron (2001), in their qualitative study, conclude that shared interest among spouse is one of their contributions to survive in marriage relationship. Married couples tend to be happier when they could be able to share similar beliefs and background. Long term and marriage satisfaction is not only for the happiness but it is a matter of shared understanding in married life. Following to that, productivity is also one of the elements that may satisfy the customers. Better productivity may result on high quality service to the customer and both efficient as well as effectiveness are required to deliver better service that will satisfy customer (Zeithaml, 2009).

Customer satisfaction is vital in order to retain and being loyalty to the organization. A few factors that affect customer satisfaction can be identified, which include courteous, friendly, helpful and knowledgeable employee, service quality, billing accuracy and timelines, quick service and good value (Harkiranpal, 2006). There are also several communication elements that might also being present in marriage life and could be apply by the spouse. Roslina (2009) discussed that service improvement can be achieved by getting feedback, comments, complaint or objections from the 
customer and based on this feedback; organization may have better view of strength and weakness of its service so that improvement can be made. Hence, in marriage relationship, it is also important to have feedback among spouse to improve their quality of relationship and achieve satisfaction (Roslina, 2009). Smiling is one type of behavior that has been identified by Soderlund \& Rosengren, 2008 , in their study where smiling worker may produce high level of customer satisfaction and may give an effect to the customer's impression in a positive way. This may indirectly will influence on the customer feelings and at the end can be intrepreted as satisfied or dissatisfied in the service that they received.

\section{Methods}

\section{Research framework}

The main purpose of this study is to identify the relevancy and relationship of customer satisfaction and marital satisfaction in regard with the service quality perspective. The dependent variable in this study is overall spouse satisfaction that is evaluated by the overall satisfaction with their service in marriage life. Whereas, the independent variable is the service perspective in which spouse measure the level of their marriage satisfaction. The perspectives included in the variables are reward, communication, behavior and responsiveness, activity and productivity.

Figure 1 The research framework

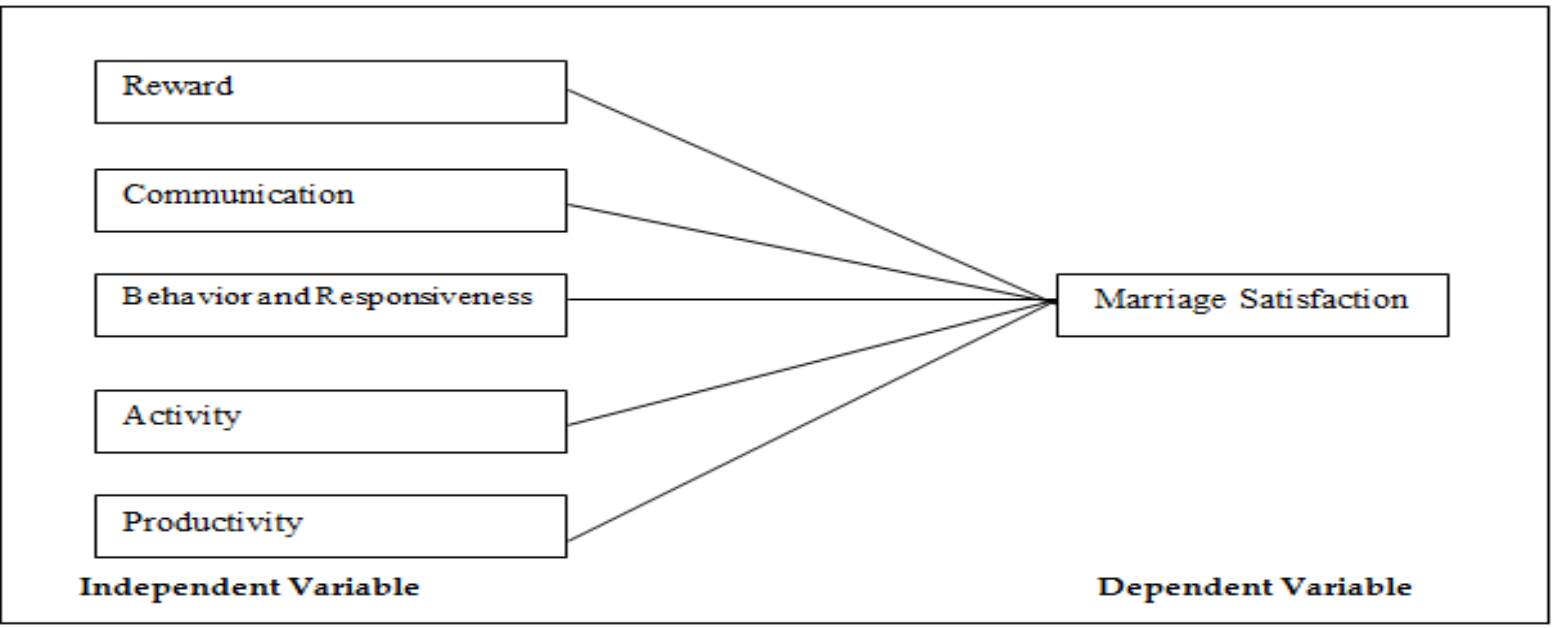

A reliability test was conducted and the results show that all variables were well above 0.80 as recommended by Sekaran (2010). Cronbach's Alpha for the five variables ranged from the lowest of 0.867 (communication) to the highest 0.910 (reward). However, for the dependent variable, the overall marital satisfaction was 0.883 that as considered good and acceptable. Thus, this confirmed that the measurement scales used for measurement of the constructs were stable and consistent, therefore the reliability of the constructs were confirmed.

\section{Results and Discussion}

The total questionnaires that have been distributed to respondents were 200, and only 190 were returned to the researcher. This gave the response rate of $95 \%$.

The data have been collected through questionnaire distributed randomly on married couples. This research evaluates 190 married couples and this represents a total 95 percent response rate of sample for population. Part one of the questionnaire is pertaining to the respondents' demographic profile. This profile was divided into seven categories, which were gender, race, age, education background, occupation, years of marriage and monthly family income.

Based on this survey, the male respondents represented 46.8 percent while the female respondents represented 53.2 percent of the total respondents. According to this survey, majority of the 
respondents were Malay which represented 86.8 percent, followed by Chinese 6.3 percent, Indian 5.3 percent and other or perhaps the foreigner were 1.6 percent.

The age distributions of the respondents were: (1) $21-25$ years old (9.5 percent); (2) 26 - 30 years old (28.4 percent); (3) 31 - 35 years old (26.3 percent); (4) 36 - 40 years old (11.1 percent); and (5) above 41 years old (24.7 percent).

It is also observed that majority of the respondents were SPM (Sijil Pelajaran Malaysia) holders, which represented 41.1 percent, followed by Diploma 26.8, bachelor Degree holders with 20.0 percent and Master/PhD holders represented of 12.1 percent. The occupation of the respondents was also being represented in this study. Most of the respondents were from government sector which was represented about 87.4 percent, respondents from private sector were 3.7 percent, students were 5.3 percent, self-employed respondents were 2.6 percent and others or perhaps the housewife were 1.1 percent.

Based on this survey, it is also represented the years of marriage of the respondents. High percentage of respondents were those with 6-10 years marriage (24.7 percent), followed by $0-1$ year (21.1) and 2-5 years (20.5 percent), 11-20 years of marriage were 14.7 percent and 21 years of marriage were 18.9 percent.

Finally, the monthly family income was also represented in this survey. It was identified that majority of the respondents were among RM 2,502 - RM 3,500 income per month, which was 29.5 percent, respondents with family income RM 3,501 - RM 5,000 were 27.9 percent, less than RM 2,500 were 28.4 percent, RM 5,001 to RM 8,000 were 9.5 percent and more than RM 8,000 were 4.7 percent only.

Table 1 Descriptive statistics

\begin{tabular}{lr}
\hline Variable & Mean \\
\hline Reward & 5.097 \\
Communication & 5.022 \\
Behavior \& Responsiveness & 4.981 \\
Activities & 5.056 \\
Productivity & 5.073 \\
\hline
\end{tabular}

Table 2 Descriptive statistics

\begin{tabular}{llcr}
\hline Reward & \multicolumn{2}{c}{ Mean } & Std. Deviation \\
\hline & $\begin{array}{l}\text { I am happy with the gift that I receive } \\
\text { from my spouse }\end{array}$ & 5.18 & 0.933 \\
\hline Communication & $\begin{array}{l}\text { I receive enough opportunities to } \\
\text { interact with my spouse }\end{array}$ & 5.07 & 0.873 \\
\hline $\begin{array}{l}\text { Behavior\& } \\
\text { Responsiveness }\end{array}$ & Supportive to each other & 5.06 & 0.852 \\
\hline Activities & We always take dinner together & 5.26 & 0.832 \\
\hline Productivity & $\begin{array}{l}\text { Collective decision making on children's } \\
\text { future }\end{array}$ & 5.19 & 0.841 \\
\hline
\end{tabular}


Table 1 shows on the descriptive statistic of the study. Reward was represented as higher mean with 5.097, followed by productivity (5.073), activities (5.056), communication (5.022), behavior and responsiveness were represented lowest mean with 4.981. Thus, from this finding, it can be concluded that reward with higher mean represented that majority of the respondents agreed that reward factor was a service dimension that could influence on their marriage satisfaction

Table 3 indicates that the R square is 0.629 and this means that the percentage of the variability between factors determine marriage satisfactions (reward, communication, responsiveness, activities and productivity) is equal to $63 \%$. That is translated to good influence factors on marriage satisfaction. In referring to table 4 , the significant p-value is equal to 0.000 , it is less than 0.05 and this means that the model of research is statistically significance. The regression analysis shows that all five independent variables namely reward, communication, behavior and responsiveness, activities and productivity represented with significance value of 0.000 . This indicated that there is relationship between these dimension with marriage satisfaction

Table 3 Model summary

\begin{tabular}{lrrrr}
\hline Model & $\mathrm{R}$ & R Square & \multicolumn{1}{c}{$\begin{array}{c}\text { Adjusted } \mathrm{R} \\
\text { Square }\end{array}$} & $\begin{array}{c}\text { Std. Error of the } \\
\text { Estimate }\end{array}$ \\
\hline 1 & $0.793^{\mathrm{a}}$ & 0.629 & 0.619 & 2.18336 \\
\hline
\end{tabular}

a. predictors: (constant), productivity, reward, responsiveness, communication, activities

Table 4 The ANOVA results

\begin{tabular}{|c|c|c|c|c|c|c|}
\hline \multicolumn{2}{|c|}{ Model } & $\begin{array}{l}\text { Sum of } \\
\text { Squares }\end{array}$ & $\mathrm{df}$ & \multicolumn{2}{|l|}{ Mean } & Sig. \\
\hline \multirow[t]{3}{*}{1} & Regression & 1438.411 & 5 & 287.682 & 60.348 & $0.000^{a}$ \\
\hline & Residual & 848.540 & 178 & 4.767 & & \\
\hline & Total & 2286.951 & 183 & & & \\
\hline & $\begin{array}{l}\text { predictors: } \\
\text { communication }\end{array}$ & $\begin{array}{l}\text { nstant), } \quad p \\
\text { activities }\end{array}$ & ductivity, & reward, & respor & veness, \\
\hline b. & dependent var & ble: satisfacti & & & & \\
\hline
\end{tabular}

\section{Conclusions}

The main purpose of this study is to determine factors influencing marriage satisfaction by using the customer service approach. Research findings indicated that "reward" (mean: 5.097) has the highest mean as compared to the others factor. The results were supported with Zeithaml (2009) that identified reward play an important role to satisfy the customer need. Therefore, marriage relationship it is also play a vital role in order to satisfy the spouse. Reward can be tangible such giving a gift or intangible such praising or being proud to each other.

Results also reveal the main factor chosen by the respondents that satisfy them in marriage relationship for each factor. Majorities were happy with the gift that they received from spouse. This could be concluded that gift or present given was being practice in the community as a part of showing concern and appreciate the spouse. In marriage, communication also plays an important role as indicated by Kiran Kaur (2010) and Rika Fatimah (2012) where they explained communication play an important role in order to satisfy the customer needs. Spouses felt satisfy when they received enough opportunities to interact to each other. This is the time where they can share their feelings, problem or any other issues. 
The ability to give respond effectively being indicated when they were managing to support to each other in many ways. Supportive in marriage relationship is important factor in determining their satisfaction. Activity such as taking dinner together was being selected as a factor that satisfy spouse. This may conclude that such activities may build harmony and time to interact to each other after being busy with their work. Finally, result shows that husband and wife were satisfy when they together make decision for the children's future such as education and career planning.

The findings of this study confirm that reward, communication, behavior and responsiveness, activities and productivity are positively related to the overall marriage satisfaction among spouses. This may conclude that the five factors of customer service approach could and being applied by the spouse in order to achieve marriage satisfaction.

The findings have brought some implications to the marriage institution and to the marriage counselors so that this new perspective may help them to resolve the marriage conflict and dissolution. Since reward is the most factor influence on marriage satisfaction, hence, this should be looked further. Husband and wife should give awareness and educate them regarding this matter so that the numbers of divorce rate will be decrease especially among Malays.

Even though the research findings provide some insights, however these findings should be viewed in light of some limitations. In summary, the limitations of this research were in term of the sample size that was only 190 respondents and majorities were among Malays and government servants. Due to the limitations above, it is recommended that necessary actions should be taken into consideration for future research in order to enhance the study of the marriage satisfaction in regards with service perspective. A bigger sample size including different races and occupations are suggested for future research. Furthermore, future research may focus on other factors in regards with service dimension such as service quality, customer commitment and loyalty.

\section{Acknowledgments}

The authors would like to take this opportunity to thank all who involved in the process of writing this paper. The encouragement we received along the way from several people kept us going strong to complete this journey.

\section{References}

Abdullah, R. (2009). A descriptive study on student's satisfaction towards the services provided by Universiti Utara Malaysia.

Ahmadi, H., \& Sadeghi, M. (2016). The role of socio-economic status in marital satisfaction. Turkish Journal of Psychology, 11(77), 43-47.

Akher, W., Abbasi, A. S., Ali, I., \& Afzal, H. (2011). Factors affecting customer loyalty in Pakistan. African Journal of Business Management, 5(4), 1167-1174.

Bachand, L. L., \& Caron, S. L. (2001). Ties that bind: A qualitative study of happy long-term marriages. Contemporary Family Therapy: An International Journal, 23(1), 105-121.

Bennett, R., \& Thiele, S.R. (2004). Customer satisfaction should not be the only goal. Journal of Services Marketing, 18(7).

Brown \& Susan, L. (2004). Moving from cohabitation to marriage: Effects on relationship quality. Social Science Research, 33, $1-19$.

Dakin, J., \& Wampler, R. (2008). Money doesn't buy happiness, but it helps: Marital satisfaction, psychological distress, and demographic differences between low- and middle-income clinic couples. The American Journal of Family Therapy, 36, 300-311.

Farzaneh, Z., Mahrokh, D., Mohamad, S., Masoomeh, S., Abbas, E., \& Sayedebatool, H. A. (2016). Effective factors in marital satisfaction in perspective of Iranian women and men: A systematic review. Electron Physician, 8(12): 3369-3377.

Fatimah, R. P. L. (2012). Improvement on marital satisfaction by using quality approach. Journal of Social Sciences and Humanities, 7(1),133-148. 
Fatimah, R. P. L., Jemain, A.A., Anuar, K. M. A., \& Saludin, M. N. (2009). Quality family deployment: A new perspective in determining priority importance for improving work performance in organization. Social Indicators Research, 92, 131-149.

Fatimah, R. P. L., Jemain, A. A., Anuar, K. M. A., \& Saludin, M. N. (2007). Quality marriage deployment in determining priority needs for initiating marriage loyalty. Quality \& Quantity International Journal, Springer Netherland, 43, 401-416.

Fatimah, R. P. L., Selvaratnam, D. P., \& Ibrahim, K. (2012). A new approach on marriage quality of marriage: The linkage between quality in organizations with marital dimensions and variables. International Journal on Social Science Economics \& Art, 2(1).

Haikal H., \& Akashah, M.N. (2007). Perkahwinan ketika belajar: Kajian kes di Fakulti Pendidikan UTM Skudai.

Hansemark, O. C., \& Albinson, M. (2004). Customer satisfaction and retention: The experience of individual employees. Managing Service Quality, 14(1), 40 - 57.

Harkinranpal, S. (2006). The importance of customer satisfaction in relation to customer loyalty and retention. UCTI working paper, WP-06-06.

Hawkins, D. N. \& Booth, A. (2005). Unhappily ever after: effects of long-term, low-quality marriages on well-being. Social Forces, Psychology and Behavioral Sciences Collection, 84(1), 445-465.

Jalal R. M. H., Haim, H. A., \& Warokka, A. (2011). Service quality and students' satisfaction at higher learning institutions: the competing dimensions of Malaysian Universities' Competitiveness. Journal of Southeast Asian Research, 855931, 10. DOI: 10.5171/2011.855931.

Jalal, R. M. H. (2011). Service quality and satisfaction among postgraduate students at Universiti Utara Malaysia.

Joan, L., Giese \& Joseph, A. C. (2000). Defining Consumer Satisfaction. Academy of Marketing Science Review, 1.

Kheng, L. L., Mahamad, O., Ramayah, T., \& Mosahab, R. (2010). The impact of service quality on customer loyalty: A study of banks in Penang, Malaysia. International Journal of Marketing Studies, 2(2).

Kumar, M., Kee, F. T., \& Manshor, A. T. (2009). Determining the relative importance of critical factors in delivering service quality of banks: An application of dominance analysis in servqual model. Managing Service Quality, 19(2), 211-228.

Osman. I., Ali, H., Zainuddin, A., Rashid, W. W. E., \& Jusoff, K. (2009). Customers in Malaysian Islamic banking international. Journal of Economics and Finance, 1(1).

Razak, A., Manaf, A., Maria, H., \& Mike, C. (2011). Understanding quality of marriage among Malays. International Journal of Humanities and Social Science, 1(4).

Salkind, N.J. (2006). Exploring Research. $6^{\text {th }}$ ed. New Jersey: Pearson Education Inc.

Saxbe, D.E. \& Repettit, R.L. (2008). Marital satisfaction, recovery from work, and Diunal cortisol among men and women. Health Pshchology, 27(1), $15-25$.

Sekaran, U. \& Bougie, R. (2009). Research Methods for Business: A Skill Building Approach. $5^{\text {th }}$ ed. John Wiley and Sons Inc.

Shafiza N. B. S. (2011). Penceraian dalam enakmen undang-undang keluarga Islam (Kedah Darul Aman) 2008. Kajian di Mahkamah Rendah Syariah di Padang Terap.

Singh, J., \& Kaur, G. (2011). Customer satisfaction and universal banks: An empirical study. International Journal of Commerce, 21(4), 327-348.

Soderlund, M., \& Rosengren, S. (2008). Revisiting the smiling worker and customer satisfaction. International Journal of Service Industry Management, 19(5), 552-574. 
Srisusanti, A., \& Zulkaida, A. (2013). Studi deskriptif mengenai faktor-faktor yang mempengaruhi kepuasan perkawinan pada istri. UG Jurnal, 7(6).

Staton, J. (2008). Making the connection between healthy marriage and health outcomes: What the research says. National Healty Marriage Resource Center.

Sureshchandar, G. S., Rajendran, C. \& Anantharaman, R. N. (2002). The relationship between service quality and customer satisfaction - A factor specific approach. Journal of Services Marketing, 16(4), 363-379.

The Chartered Institute of Marketing. (2009). 10 Minutes Guide: Customer Service Programme.

Vukmir, R. B. (2006). Customer satisfaction. International Journal of Health Care Quality Assurance, 19 (1), 8-31.

Yaya, L. H. P., Marimon, F. and Casadesus, M. (2011). Customer's loyalty and perception of ISO 9001 in online banking. Industrial Management and Data Systems, 111(8), 1194-1213.

Zeithaml, V. A., Pitner, M. J., \& Gremler, D. D. (2009). Services Marketing: Integrating Customer Focus Across the Firm. 5th Edition. McGraw Hill. 